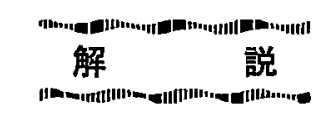

STOL 機についで

佐々木義 雄**

1. はじめに

V/STOL 機の開発は軍用俉始まり幾多の研究がな され多くの試作機が作られた. しかし試作機のほとん どは消えて，試練に耐えて生き残ったものとしては VTOL では H.S. Harrier ぐらいのものである. STOL でも Breguet 941 がまあ残るかというとと ろ, 新明和 PS-1 あ成功した STOL と言えよう.

輸送手段としての V/STOL は CTOLに比して取 得価格や運航費が高くなるので，見在まで本格的なる のが出現するに到っていない. しかし技術の進歩。社 会環境の変化 (空港問題) と相まって人間の時間価值 がますます貴重になってきた現在, STOL 輸送の必要 性は本格的に論ぜられるようになってきた。

米国では 1980 年代の実用を目ざして STOL 輸送 システムが NASA 等によって研究開発されつつあ る. カナダは政府が力を入れて試験運航に入ろうとし ている. その他欧州諸国もSTOL の研究を続りてい る. 我国でも昭和 46 年 12 月の航空技術審議会 8 号答 申に格いて “V/STOL 機開発技術の確立の必要性”が 答申され，最近では科学技術庁，通産省等諸機関によ るSTOL 输送システムの研究が始められている.

本解説では輸送システムとしての STOL について, システム全般の問題点之機体の技術的問題点について まとめた結果を御紹介したい.

\section{STOL 機の定義}

“通常の航空機に比へて滑走距離が短く離着陸の飛 行経路角が大きいあの”あるいは軽飛行機等之区別し で翼面荷重は大きくCTOLなみの飛行速度を持っ ているが, 離着陸時に特別な揚力增加装置を使用し て STOL 性を発揮する機体”など一般にはく然と言 いあらわされている. 具体的な定義つけをした例と しては Hawker Siddley 社の定義”（第1四）があ り，てれに上れば滑走路長 $1,500 \mathrm{ft} \sim 3,000 \mathrm{ft}$ の機体 をSTOL と定義している.

\footnotetext{
* 昭和 49 年5月 23 日原稿受理 A Prospect of STOL Aircraft

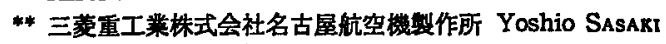

\section{STOL 輸送システムの効用}

船や鉄道に比へて航空輸送が経済的にどうかと言う 点からマクロに比較した例を示す. 輸送機関の速度に 対して䠼送效率 $\left(W_{p} \cdot V\right)$ あたりの消費エネルギ (HP) をプロットしたあのを第 2 図に，同様に機体価格を第 3 図に，運貨を第 4 図に示す ${ }^{2)}$. 一般的に言って早い

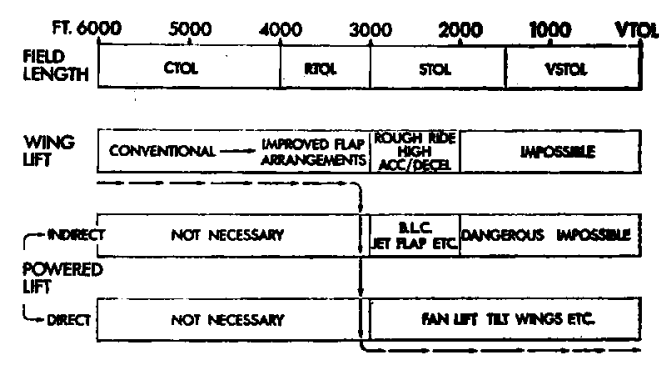

第 1 図 STOL 滑走路長の定義（例）

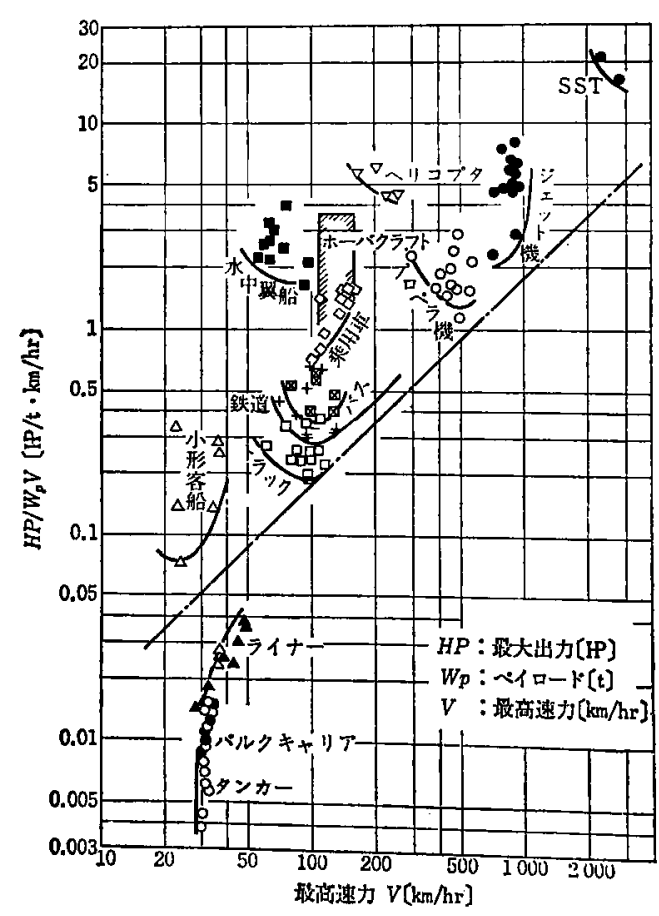

第 2 図 交通機関の $\mathrm{F} / W_{0} V$ と $V$ の関係 

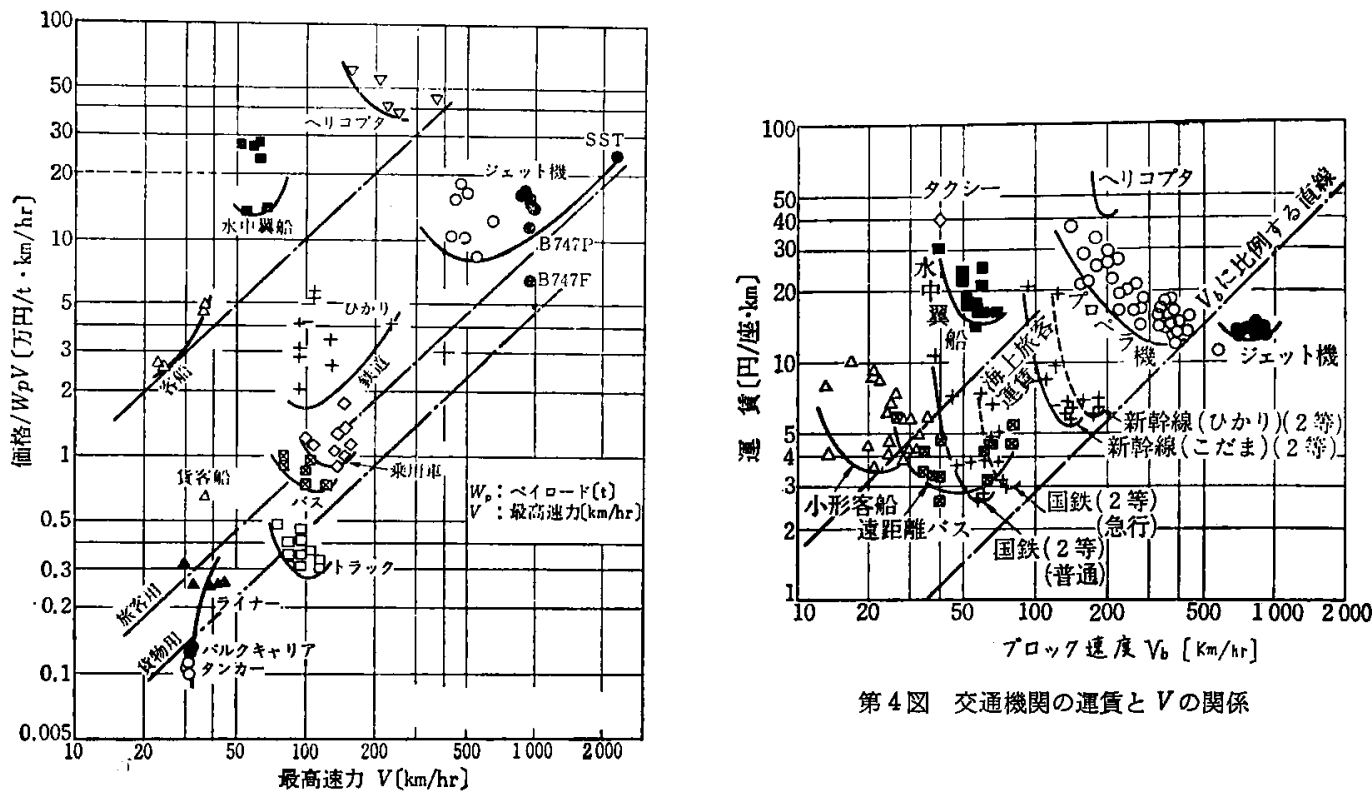

第 4 㘡 交通機関の運貢と $V$ の関係

第 3 図交通機関の価格 $/ W_{p} V$ と $V$ の関係

第 1 表 交通機関の路線別評価表

\begin{tabular}{|c|c|c|c|c|c|c|c|c|c|}
\hline \multirow{2}{*}{ 路 線 } & \multirow{2}{*}{ 区 分 } & \multicolumn{2}{|l|}{ 鉄 } & \multirow{2}{*}{ 高速バス } & \multicolumn{2}{|c|}{ 航 } & 空 & 海 & 上 \\
\hline & & 在 来 線 & 新 幹線 & & CTOL & STOL & VTOL & 汽 船 & 水中翼船 \\
\hline \multirow{3}{*}{ 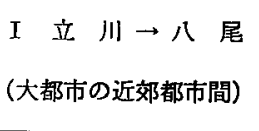 } & $\mathrm{U}$ & 60 & 77 & 62 & 69 & 82 & 79 & \multirow{2}{*}{-} & \multirow{2}{*}{-} \\
\hline & S & 67 & 77 & 73 & 54 & 68 & 59 & & \\
\hline & $\mathrm{T}$ & 64 & 77 & 68 & 62 & 75 & 69 & & \\
\hline \multirow{3}{*}{$\begin{array}{l}\text { II 名古屋 } \rightarrow \text { 輪 島 } \\
\text { (大都市と地方都市間） }\end{array}$} & $\mathrm{U}$ & 68 & 79 & 65 & 66 & 75 & 69 & \multirow[t]{2}{*}{-} & \multirow{2}{*}{ - } \\
\hline & $s$ & 82 & 79 & 81 & 60 & 70 & 59 & & \\
\hline & $\mathrm{T}$ & 75 & 79 & 73 & 63 & 73 & 64 & & \\
\hline \multirow{3}{*}{$\begin{array}{l}\text { III 宇都宮 } \rightarrow \text { 捠 松 } \\
\text { (地方都市相 互 間) }\end{array}$} & $\mathrm{U}$ & 73 & 87 & 71 & - & 78 & 75 & \multirow{2}{*}{-} & \multirow[t]{2}{*}{-} \\
\hline & $S$ & 82 & 89 & 82 & & 70 & 61 & & \\
\hline & $\mathrm{T}$ & 78 & 88 & 77 & & 74 & 68 & & \\
\hline \multirow{3}{*}{ 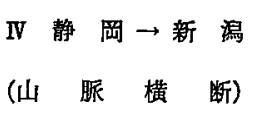 } & $\mathrm{U}$ & 57 & 76 & 63 & 60 & 78 & 75 & \multirow{2}{*}{-} & \multirow{2}{*}{-} \\
\hline & $\mathrm{s}$ & 71 & 84 & 75 & 49 & 66 & 56 & & \\
\hline & $\mathrm{T}$ & 64 & 80. & 69 & 55 & 72 & 66 & & \\
\hline \multirow{3}{*}{$\begin{array}{l}\text { V 川 崎 } \rightarrow \text { 新 島 } \\
\text { (本社 と離 島 間) }\end{array}$} & $\mathrm{U}$ & - & - & - & 57 & 75 & 69 & \multirow{2}{*}{$\begin{array}{l}28 \\
25\end{array}$} & 64 \\
\hline & $S$ & & & & 46 & 63 & 61 & & 54 \\
\hline & $\mathrm{T}$ & & & & 52 & 69 & 65 & 27 & 59 \\
\hline \multirow{3}{*}{$\begin{array}{l}\text { VI 名古屋 } \rightarrow \text { 珠 洲 } \\
\text { （大都市之 钼 光 地 間） }\end{array}$} & $\mathrm{U}$ & 64 & 75 & 64 & 56 & 81 & 78 & \multirow{2}{*}{-} & \multirow{2}{*}{-} \\
\hline & $\mathbf{S}$ & 78 & 72 & 78 & 54 & 71 & 61 & & \\
\hline & $\mathrm{T}$ & 71 & 74 & 72 & 55 & 76 & 70 & & \\
\hline \multirow{2}{*}{ VII 大 阪 $\rightarrow$ 足摺呷 } & $\mathrm{U}$ & 49 & 80 & \multirow{2}{*}{-} & 66 & 75 & 72 & \multirow{2}{*}{$\begin{array}{l}53 \\
62\end{array}$} & 51 \\
\hline & $\mathbf{s}$ & 62 & 71 & & 51 & 69 & 59 & & 59 \\
\hline （海＼cjkstart峡＼cjkstart横＼cjkstart断） & $\mathrm{T}$ & 56 & 76 & & 59 & 72 & 66 & 58 & 55 \\
\hline
\end{tabular}

（注） U：ユーザ・サイドの評価（運賃，時間，安全性，定時性，快適性）

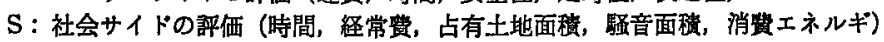

$\mathrm{T}$ ：UとSの評価の平均 
乗物は高くつくこと, 航空の中です VTOL (ヘリコ プタ）は相対的に高いととがわかる. STOLはこの中 間に位する。

しかし STOL には次の如き利点がある.

（1）空港混雑の楥和

(2) 騷音公害の縮少

（3）総旅行時間の短縮

(4) 都市間交通の至便化

(3)，(4)については，既に言い慣らされているととろで あるが，最近では(1)，(2)の面が強調されつつある，乙 の点については，4節であう少し詳しく述べるととに する.

昨年社会工学研究所が中心でなされた “都市間交通 におりる V/STOL の役割了”という研究の中では， 1980 年代仁捄ける我国都道府県間の人員総流動量を 求めその中で STOL のシェアを予測し，てれを足が 加りとして 1990 年代の V/STOL の役割を求めようと している．乙の一節に各種交通機関の路線別総合評価 をした例がある．これを第 1 表に示すが，STOLに適 すると思われる 7 種の性格の路線加ら代表ケースを選 定し, 各種評伍項目についての判定を行なって STOL の勃用を探ろうとしたすのである，ただし鉄道は新幹 線計画のある所比はてれを走らせて在来線と連絡す る. CTOL は在来空港のみ使用し，他の交通機関之連 䊀させる. V/STOL は近くに V/STOL 空港ができる という仮定である. 第 1 表は注記に示す如き評価項目 に適当な重みづけをして各種交通機関の百点満点によ る得点をまとめたすのである。これによると新幹線の 得点が高いが，STOLもこれに次ぐ得点を得ている. CTOLはアクセス・タイムが長くかかるため, VTOL は運顀が高いために得点が下がっている。

\section{STOL 輸送システム成立の条件}

勃果的な STOL システム成立の条件として次の 3 つが必須と考えられる。

(1) STOL 機の出現

(2) STOL 空港の設置

(3) STOL 航法システムの確立

(1)については次節以降に述へることとして，(2)，(3)に ついて簡単に触れておく。

4.1 STOL 空港 航空需要の進展化伴い航空機の 高速, 大型, 長距離化が進み, 必要滑走路長は 3,000 $\mathrm{m} \sim 4,000 \mathrm{~m}$ 之長くなり飛行場は拡張されてきた.し 加し近年の航空旅客の急增により拡張は限度にきて, 第 2 ，第 3 の大空港が要るようになってきた。ところ で最近の社会情勢では大空港の取得は極めて難しい問 題になっており，例えばニューヨークは現用 3 空港の
ほかに第 4 空港を 10 年前から探しているが末だ適地 が見つからない．ロンドンでは第 3 空港の選定をめぐ り住民の反対運動があり，都心より極めて遠隔の地に 侯補地を設定せざるを得なかった(マプリン空港計 画). 東京の第 2 空港成田の猛反対運動は今あ続いてい る. 大阪あ海に第 2 空港を作る以外に手のない現状で ある.

STOL 空港がどの程度の規模が良いかと言うこと は，前提条件の置き方によって一概には言えないか， FAA が暫定的に STOL の滑走路長を $1,500 \mathrm{ft}$ とし 都市における標準的 STOL 空港として 8 万 $\mathrm{m}^{2}$ 規模の 図を示している(). 社工研の前述の研究の中にすST. OL 空港と CTOL 空港の規模を比較した武算があ る5)。これによると滑走路長をそれぞれ $500 \mathrm{~m} ， 2,000$ $\mathrm{m}$ として両端䎲適当な Clear Spaceを取り，幅侸余裕 を取って 2 万 $\mathrm{m}^{2}$ のエプロン面積を取った場合, STOL 空港は 16 万 $\mathrm{m}^{2}$, CTOL空港は 74 万 $\mathrm{m}^{2}$ と約 5 倍にな る.また BAC 社の比較では, single runway の CTOL 国際空港は 560 万 $\mathrm{m}^{2}$ に対 L, STOL 空港は 65 万 $\mathrm{m}^{2}$ で足りるとしている(約 $\left.1 / 10\right)$ ）以上のてと は, STOL 機の DOC が多少高くても空港取得 価格 を含めたシステム全体のコストを考えた場合，STOL が CTOL よりあ経済的に有利になる可能性があるこ とを示している。

人口の密集する都会におりる空港用地の入手難につ いて以上の検討から STOL の有利性が理解できるが, 更に大きな問題として空港周辺の騒音の問題がある. STOL は進歩した騷音低減技術を探用し，滑走路が短 く飛行径路角が大きいという特徽を生かして，乙の面 であ CTOL に比して有利になると考えられる. 第 5 図は STOL 機の目標值である“500 ft 側方で 95PN$\mathrm{dB}$ ”が実現した場合の騷音面積を CTOL のそれと比 較したものである゙ ${ }^{6}$. 騒音面積は $1 / 4 \mathrm{mile}^{2}\left(64\right.$ 万 $\mathrm{m}^{2}$ ) で STOL 空港面皘のオーダである.これに対し CTOL はFAA の基準に合う騷音の機体で $7 \mathrm{mile}^{2}(1,800$ 万

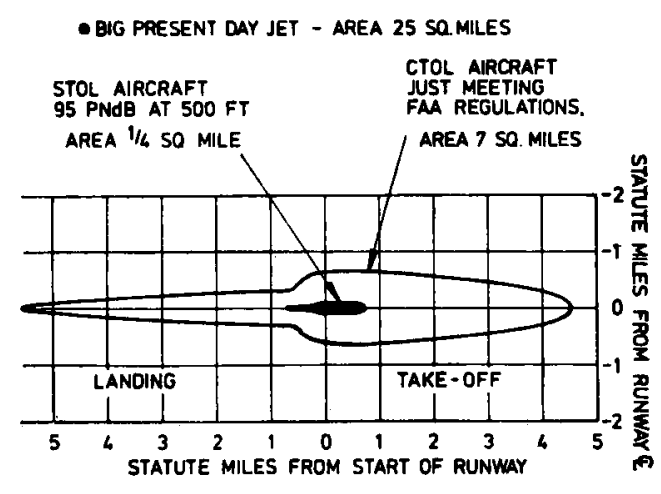

第 5 図 STOL と CTOL の蛪音面䅡 
$\left.\mathrm{m}^{2}\right)$ となり羽田空港 $\left(340\right.$ 万 $\left.\mathrm{m}^{2}\right)$ の約 5 倍となる. 現 用大型ジェットの騒音面皘は更にとれの 3〜4 倍とい うことになる.

4.2 STOL 航法システム 旅客の増加に伴って 航空路の混雑, 空港の混雑から滞空や地上待機が目立 ってきて定時性が著しく阻害されるようになってき た.とれを解決する手段として area navigation と microwave instrument landing system がある. 前者 は従来の航空路のほがあいている空間を利用しょう とするすので，任意の直線コースを選ふと加従来の航 空路に平行してコースを選ぶとかの方法がある. VOR /DME の地上航法援助施設を利用して, 機上コンピ ュータにあらかじめセットされた飛行データに従って 飛行する. 後者は従来の VHF, ILS が地形や建造物 の反射の影響が大きく設置場所が限られかつグライ ド・スロープ，ローカライザのビームが固定であるの に対して，反射の影響が小さく設置容易でありビーム の SCAN が可能である新しい方式の ILS である. STOL の如く旋回しながらアプローチしたり，降下角 大でアプローチする場合はこのような新方式の ILS が必要である. 米国では MDC-188 (Breguet 941 の 改造譏)にてれらの機器を搭載して，FAA 参加の下 にアメリカン航空, イースタン航空が運航実験を行な い，との結果 STOL 空港設置基準が FAA より発表 されている。

STOL 輸送システムの勃果を十分敒発揮するために は，てれらの航法システムの確立が必須の条件である と考えられる。

\section{STOL 機の開発状況}

現在諸国で考えられている STOL 輸送機の形式と その開発状況を以下に簡単にまとめる。

5.1 プロヘラ後流偏向方式

（1） DHC-7（第6図）カナダがカリプー，バフ フ只の経験を生加して 4 発 48 人乗の STOL 輸送機之 して開発中の機体である. 1974 年後半に初飛行が予定 され，その 1 年後に型式㫌明の取得が予定されてい る. また機体開発と平行して, 政府之産業界が拹力し $\tau$ STOL Industry System Office (ISO) を設立し, 航空会社, 電気会社, コンピュータ会社等 10 社が参 加して通産省との契約で運営し，STOLシステム評価 のため市街地に $2 つ の$ STOL 空港を作り， 3 機のツ インーオッターによる試験運航を行なう計画もある.

(2) MDC-188F (Breguet 941) MDC 社加 Breguet 941 を改造して STOL システム評価試験に供し たものである. イースタン航空，アメリカン航空が FAA の支援のもとに評価試験を行なった．アメリカ

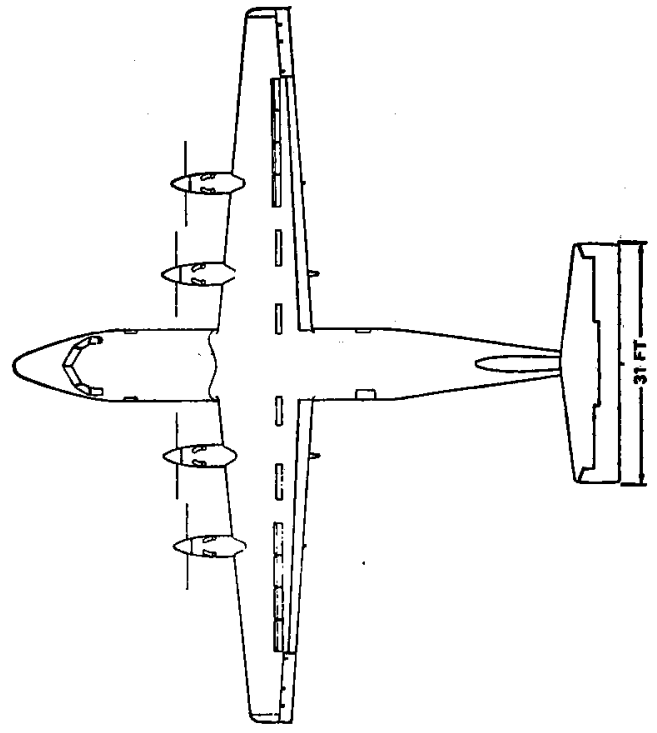

第 6 图 DHC-7

ン航空はプロペラ STOL 機を米国東海岸の North East Corridor に使用するととを検討したが，50１00 席の STOL は経済的運航はできないとの結論に達 し，その後米国ではプロペラ STOL の開発計画は中 断している.

\section{2 Tilt Wing, Tilt Engine}

（1）CL-246 CANADAIR 社では CL-84 を改造 して 4 発 70 席の tilt wing 式プロペラ STOL を計画

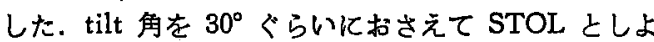
うという計画であったが，カナダ政府はこのプロジェ クトを取上げず. 米国の援助を期待しているが乗って いない.

(2）仏エアロスパシアル社 tilt wing, tilt engine を研究したが，現芰術レペルでは機構複雑で実用でな いとの結論である.

\subsection{Lift Fan, Lift Engine 方式}

(1) HS-141 16 基の RB $202(13,000 \mathrm{lb})$ リフ ト・エンジン, 100 席の V/STOL 計画であるが. 開発 に政府の援助が得られるかどうかが問題である。

(2) Do-231 Do-31E 実験機を基礎化 12 基の RB 202，100 席 V/STOL の計画. Do, VFW，MBB 劦同 で政府に提案している．国際共同開発が必須と考えら れている。

5.4 Augmentor Wing (第 9 図参琞)

（1）Buffalo 実験機（第 7図）加, 米両政府共 同プロシェクトで, augmentor wing (AW) concept の評価の目的でバプロ改造機に Spey エンジンの改 造型を搭载した AW 実験機である. Boeing 社が改 造を実施して 1972 年初飛行し，現在飛行実験が綕け 
られている。

5.5 Externally Blown Flap (第 9 図参照)

(1) NASA QUESTOL 計画 NASA は EBF, AW 両方の concept を実験できる QUESTOL (Quiet Experimental STOL) 計画を持っており, 当初 1974 年末初飛行を目指したが，1973 年度当初予算は 削除された．その後予算は復活したがスロー・ダウン される模様である.

（2）USAF AMST 計画（第 8 図参照)

Advanced Medium STOL Transport (AMST) $\&$ 称する軍用の STOL 輸送機 (ペイロード13トン) で ある. 1972 年末 Boeing 社および MDC 社㜔競争試 作契約がなされた. 1975 年初飛行の予定である. Boeing 案は upper surface blowing (第9図参炤) Type, MDC 案は lower surface blowing type を操 用している.

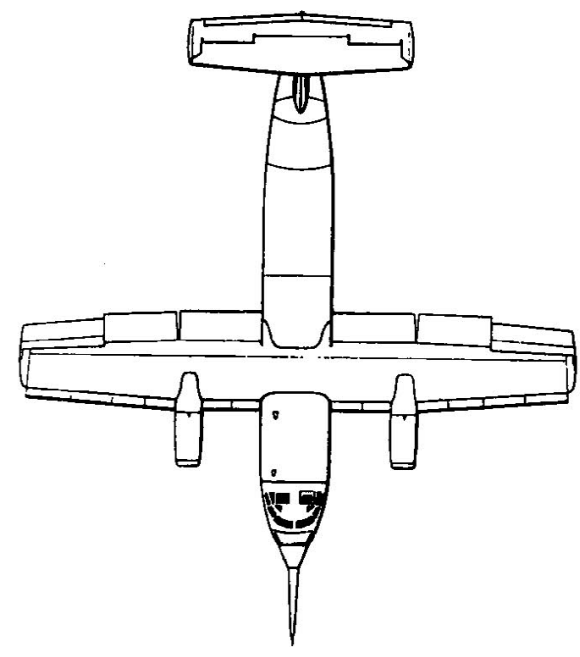

第7四 NASA AW 実験機

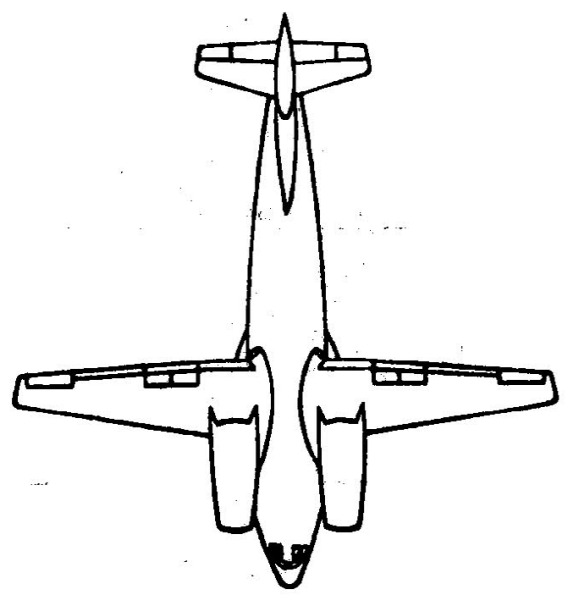

第8图 AMST, B社案
以上諸外国のすう勢加ら見て判る如く，STOL機の 形式は世界でまだ決定的な方向が決まったとは言えな い状況にあるが. プロペラ STOL では後流偏向方式 の DHC-7 が先行し, シェット STOL では AW を 含む blown flap 形式 (いずれも powered high lift

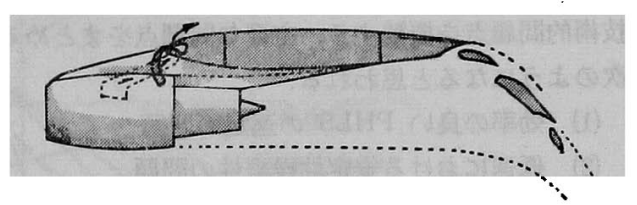

Externally Blown Flap
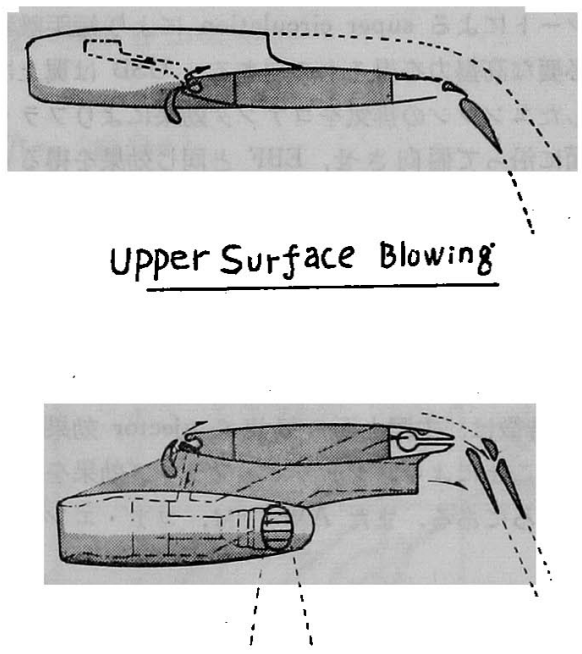

Augmentor Wing

第9因 有望な PHLS 形式

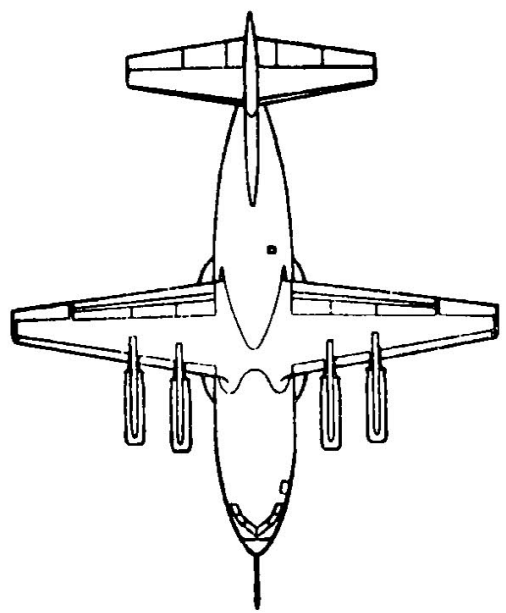

（上）および MDC 社案（下） 
system）が比較的有望な形式と目されているととがわ 功る。

\section{STOL 機の技術的問題点}

本節ではターボフォン・エンジンによる powered high lift system (PHLS) を用いた STOL 旅客機の 技術的問題点を概観する. 主要な問題点をまとめると 次のようになると思われる.

（1）効率の良い PHLS の選定の問題

(2) 低速における安定性操縱性の問題

(3) 騷音の問題

6.1 勃率の良い PHLS の選定の問題 現在比較的 有望と目されている 3 つの PHLS 形式を第 9 図に示 す. EBF は翼下に装備したエンジンの排気をフラッ プにより偏向させ，推力偏向による直接揚力とジェッ ト・シートによる super circulation により短距離着 陸に必要な高揚力を得るすのである. USB は翼上に 䒾備したエンジンの排気をコアンダ勃果によりフラッ プ上面に沿って偏向させ， $\mathrm{EBF}$ と同じ効果を得るも のである.この 2 形式は総称して外部吹付け型 (externally blown type) 之呼ぶことができるが，3番目の $\mathrm{AW}$ は，エンジンのファン気流を翼内のダクトを通 して後縁の 2 枚のフラップの間を通して吹出すととか ら, 内部吹出型 (internally blown type) と呼ばれる. AW の特徽は，主翼上面の気流を ejector 效果によ り引込むととにより.ジェット・フラップ効果を增強 するとてろにある.また $\mathrm{AW}$ では,コア・エンジン

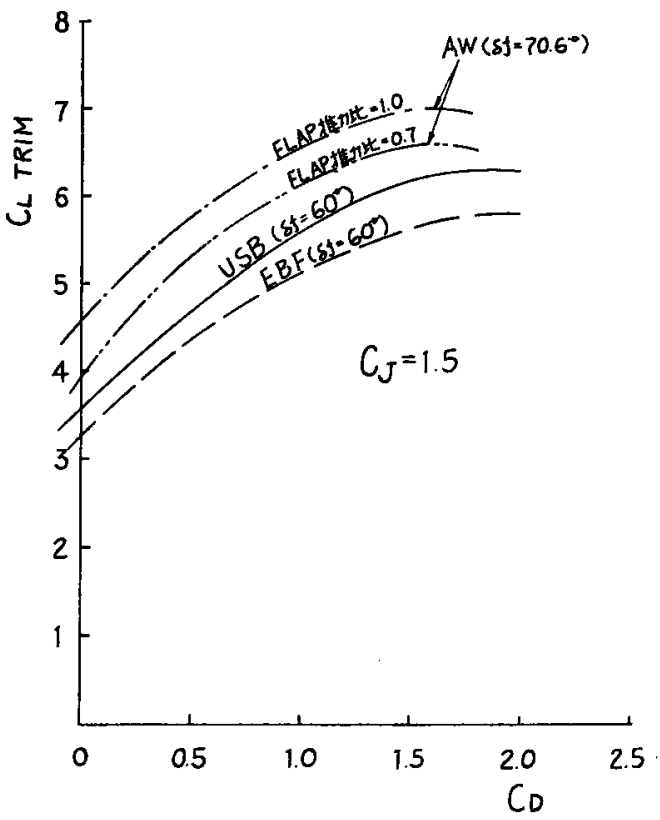

第 10 図 PHLS の空力特性
推力を vector nozzle により $90^{\circ}$ 以上回転させるとと ができ，乙れを推進力之直接揚力の両用に用いるとと ができる.

これらの形式の空力特性は, NASA の風胴実験で かなり確かめられている 係数 $C_{J}\left(=T_{G} / q S\right)=1.5$ Kおける各形式着陸形態のト リム状態における $C_{L} \sim C_{D}$ を示す. ただし $\mathrm{AW}$ の場 合は, フラップ推力比 $100 \%$ および $70 \%$ (コア推力 $30 \%$ は直接揚力飞使用）について示す. 同一CJの とでは， $\mathrm{AW}$ が $C_{L \text { max }}, C_{D}$ とあ特性か最も良好であ るととがわかる。

離着滑走路長と翼面荷重, 全機推力重量比の関係を 検討した結果を第 11 図に示す．これは上述の文献の 空力特性を用いて離着陸性能を計算した結果であっ $\tau$, 各形式の $W / S$ と $W / T$ の積に対する路長の関係 を示し，各線上では離陸路長と着陸路長が一致してい る. 同じ路長要求に対し $(W / S) \cdot(W / T)$ が大きいほぼ 高揚力装置の空力的な効率が良いから，との図加ら第 10 図加ら判断されると同じく，AW が最も良いとと がわかる. USB は AW こ EBF の中間に位している が，文献(8)における風胴試験模型ではフラップ後縁延 長板により大きなコード延長を行なっているので，実 質的には古う少し EBF に近い特性になると思われる.

第 12 図は，路長を $2,000 \mathrm{ft}$ 亿怙さえたときの $\mathrm{AW}$ の必要推力を示すむのである. (W/S $\left.=400 \mathrm{~kg} / \mathrm{m}^{2}\right)$. フラップ推力とコア推力の分配を変えたときの全必要 推力の変化を示し, フラップ推力/全推力 $=0.7$ で全推

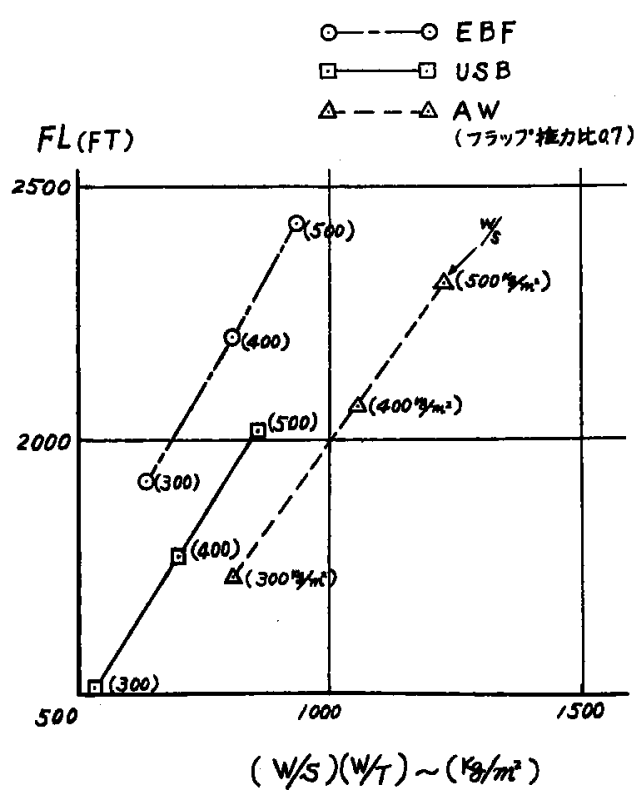

第 11 図 敞者陸滑走路長と $(W / S) \cdot(W / T)$ 
$(T / w)_{\text {CORE }}$

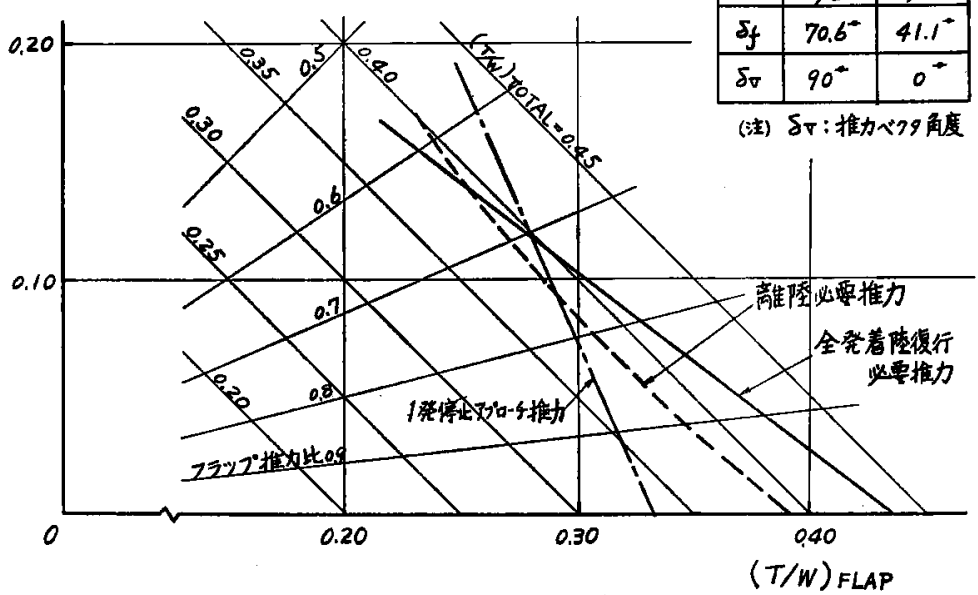

第 12 因 $\mathrm{AW}$ フラップ推力比と必要推力の関保 $(\mathrm{F} . \mathrm{L}=2,000 \mathrm{ft})$

カが最小となることを示す。ただし最適フラップ推力 比の選定は，エンシンンの性能と合わせて検討する必要 がある.

PHLS の形式の選定の問題は, 空力特性のみでな く, 後に述べる安定操緃性, 騒音の問題のほか, 高揚 力装置の機構, 構造の問題, STOL 用エンジンの性能 (SFC 等) p実現性の問題, 技術的難易度およびコス 卜の問題等, 綜合的に考える必要があり, 各形式の空 力的な洗練とととあに今後さらに研究を重ねる必要が あると思われる。

6.2 低速における安定性操縦性の問題 STOL 機 の低速における安定性操緥性上の問題点を一般的にま とめると次のようになる。

(1) 舵面の勃きの減少 (1/2 $\rho V^{2}$ 小).

(2) 応答か子遅い. $\Delta n z / \Delta \alpha$ が小.

(3) 速度不安定が大. (パック・サイド運用)

(4) aerodynamic damping $の$ 減少.

(5) aeredynamic cross coupling 加大.

（6）横風および突風の影響が大.

（7）エンジン故障によるモーメントの影響が大。

滑走路を短くする要求から着陸地点の正確さがCT. OL 以上に要求されるので, 以上の問題は非常に重大 となる。，一例として絿の応答を表わす $n_{\boldsymbol{x} \alpha}$ は，ジェッ ト STOLに㭁いては CTOL の 1/3 に低下する ${ }^{10}$ (第13図)．また径路角の安定上，速度不安定域での 通用が問題になる. これらの安定操程道上の問題の解決 のため, 安定増強装置 (SAS) や, direct lift control, automatic throttle 等進歩した control augmentation system の採用が必要になろう.なお Buffalo 改造 $\mathrm{AW}$ 実臨機のシミュレーション結果によると，径路変更を

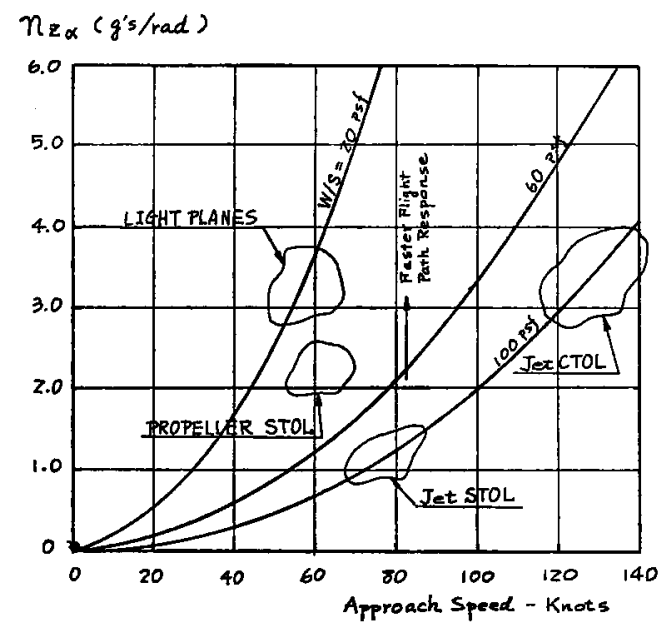

第13図 STOL 機の nะa

昇降舵で行なうのは速度不安定のためまずく，vector nozzle の回転によるのが最すよいということになって いる'11.

また，STOL機の安全性を確保する上では，低速で のエンジン 1 発停止時の飛行性か哏好であるととが最 あ重要である．上述の Buffalo 実験機では，1 発停止 時任生きているエンジンのコア推力による横摇れモー メントが大きので，クロス・ダクトにより反対側の翼 にフラップ・エアを余分に分配して釣合わせている。 また補助翼 (BLC 付)のほ加に augmentor air の choke, spoiler を使用して横操粉能力を增強している (第 14 図). externally blown 形式では,クロス・ダ クト方式がとれないので, 1 発停止時の横摇れモーメ ントはさらに大きくなり，BLC 補助翼，差動フラッ 

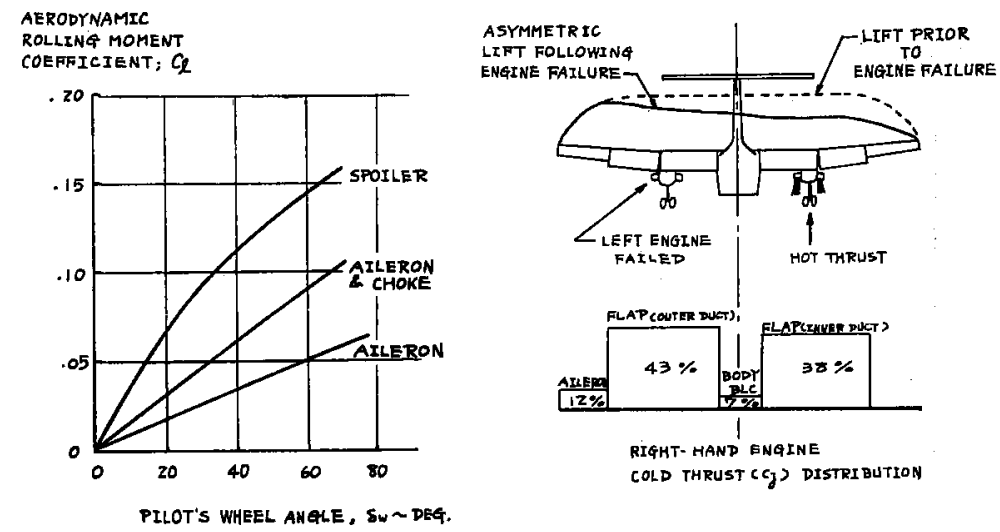

第 14 因 NASA AW 実倹機の横操㮶システム

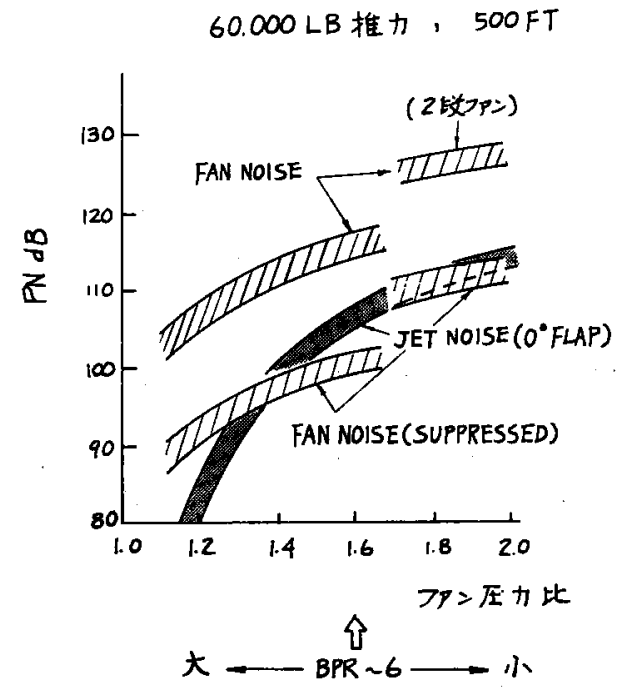

第15四 ターボファン・エンシンの騷音

ナ・・ンシン排気のスパン方向への tilt，等によりさ らに強力な横操縦能力を必要とする.

STOL 機の安定性操梲性には未だ未知の分野が多く 今後シミュレーション試験のみならず，実用機の開発 の前段階として実験機による試験運用が必須であると 思われる.

6.3 STOL 機の騒音問題 4.1 節に触れたように, 進歩した騷音低減技術の採用之短い滑走路長，大飛 行径路角の特徽を生かして STOL 機の騒音面皘を CTOL に比へて大幅に減らすととが目論まれている. NASA は STOL 機騒音の目標值を, “500ft サイド・ ラインで 95 PNdB” に置いている.

STOL 機の騒音源は, CTOL 機と同様にエンジン のフォン騒音とシェット騷音が主体となるが，CTOL と異なりジット排気とフラップの千造によりジェッ ト騒音が大幅に增幅されるという新たな問題が生じる

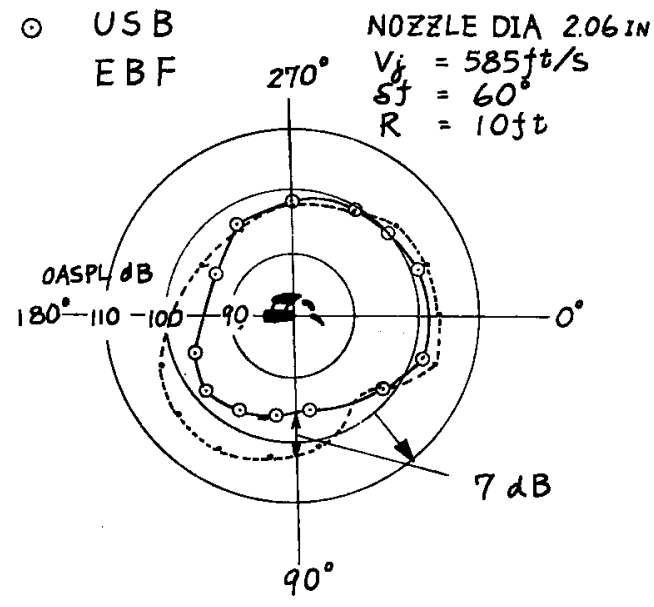

第 16 図 PHLS 干涉騷音 (EBF)

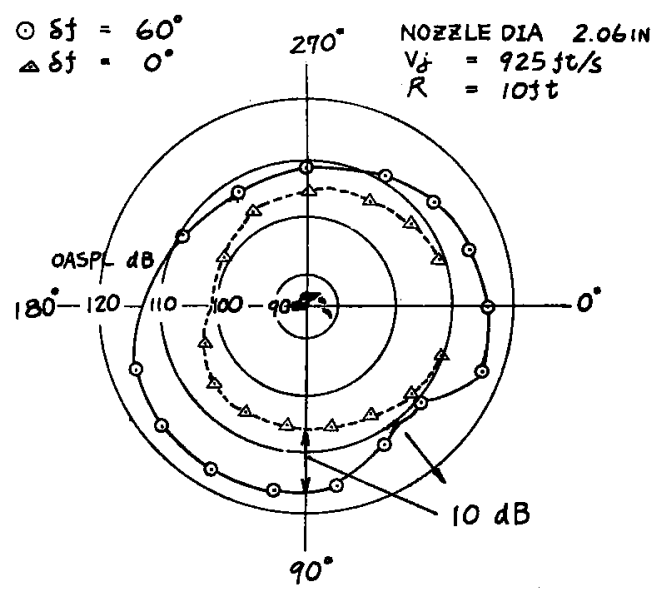

第 17 四 PHLS 千涉騷音 (USB)

((PHLS 騷音).

第 15 困は,ターボフォン・エンジンのファン騒音 とジェット騒音の㑯向を示す ${ }^{12)}$. 現用のパイパス比 6 


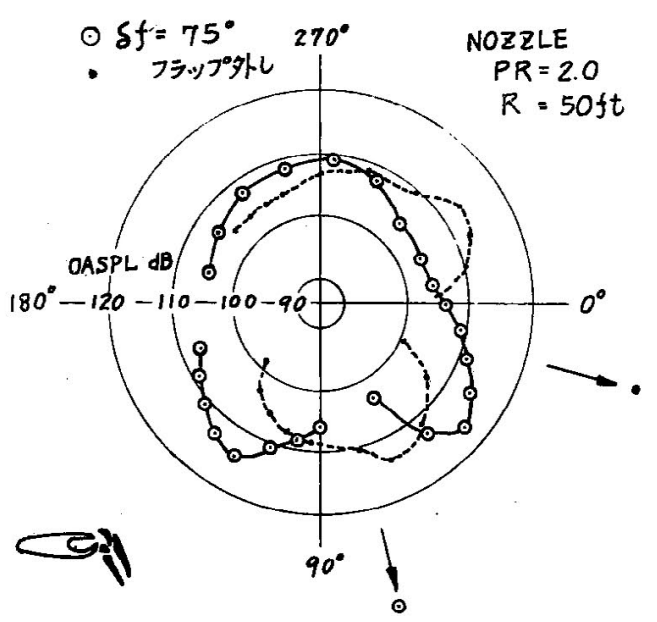

第18図 PHLS 干渉騷音 (AW)

ESTIMATE OF MAXIMUM 500-FT-SIDELINE

FLAP NOISE OURING TAKEOFF

170,000 LB GROSS WEIGHT AIRPLANE; 94,000 LB THRUST IA ENGINES:

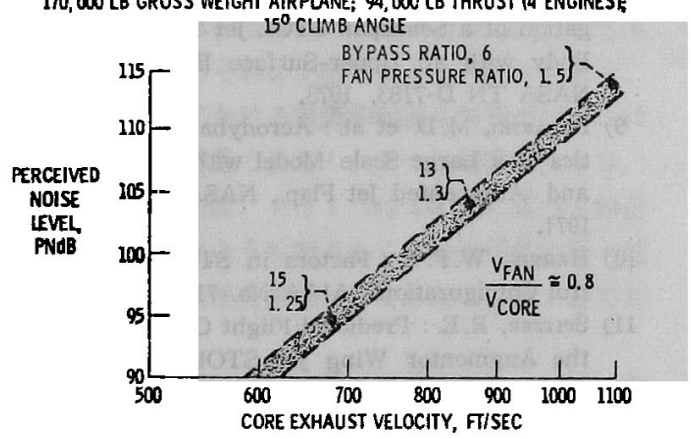

第 19 図 $\mathrm{EBF}$ 干渉馶音と排気速度の関係

程度のエンジンのファン代力比は 1.5 1.6 程度であ り，吸音材なしではファン騒音がジェット騒音よりあ 大きくなっている。しかし図化示すように進歩したナ セ儿吸音処理によりファン騒音を 15 20 dB 低減でき る見通しが立てられている. この場合ファン代力比 1.3 (パイパス比約 13) ぐらいでファン騒音が STOL 目標値におさまる，ただし $\mathrm{AW}$ の場合は，翼内ダク トのスペースの関係でファン圧力比を下げられない (匠力比 2 以上) ので，ファン騷音を $25 \sim 30 \mathrm{~dB}$ 下げ る必要があり，チョーク・インレットの採用が必要に なる。

前述の PHLS 騷音は，第 16〜18 図に示す如くであ る (NASA の模型試験値 ${ }^{13)}$ ). EBF はジェット排気が フラップにあたるととにより，約 $10 \mathrm{~dB}$ の騒音增加が 生じる (第 16 図)，USB は翼上面に騷音源があるの で，翼の遮へい効果により $\mathrm{EBF}$ より約 $7 \mathrm{~dB}$ 低くなる (第 17 図). AW では nozzle jet と flap の干渉によ り ejector 出口両側に増幅された noise peak が生じ

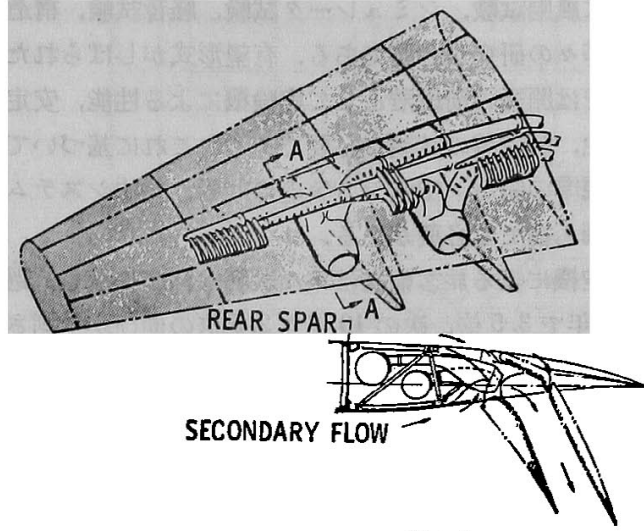

SECTION A-A

第 20 図 AW 干涉駿音の低娍対策

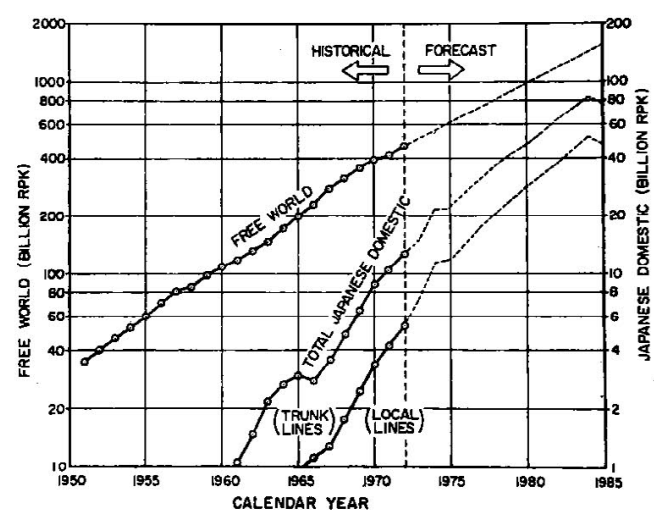

第 21 図 航空旅客の伸び15

る(第 18 図).

てれらの干涉騒音を隇少する方法として，EBF（お よび USB) では, 高バイパス比のエンジンを使用し て，フラップにあたる排気速度を下げるのが最も効果 がある ${ }^{13)}$ (第 19 図).

AW では第20困に示すような multirow-lobe nozzle や ejector 内部の吸音材による騷音低減が考え られている ${ }^{14)}$. てれらの騒音低減対策により PHLS 騒音は一応 STOL 目標値内におさまる見通しが立て られている.

\section{7. まとめ}

以上 STOL 輸送システムの勃用, 問題点を論じ, 特に機体については最近有望視されているターボフォ ンSTOL 譏についてやや詳しく紹介したが, 我国敒 あ適する STOL システムの開発にはプロペラ STOL からダクテッド・ファンV/STOL にいたる広い䉓囲 にわたって,エンジンの開発と合わせて利害得失をよ く原点にかえって ORし，また諸外国の今後の成行き を注視しつつ形式をしはる研究を始める必要がある. 
てれに風胴試験, シミュレータ試験, 騷音試験, 構造 試験等々の研究が必要である. 有望形式がしばられた 段階では開発の前段階として実験機による性能, 安定 操緥性，騷音等の試験が必要である。これに基づいて 規定規準の制定, 空港システムの計画，航法システム の計画も樹てる必要がある.

航空機による旅客輸送は年々順調な伸びを示し, 過 去 10 年で 3.5 倍, 次の 10 年も 2.5 倍の伸びが予測さ れ，特に日本ではこの倍のオーダで伸びている.(第21 因).これにともなって空港の混雉や騷音の問題がクロ ーズアップされてきて解決は早急をせまられている。 STOL は空港面積が少なく，騷音面皘が狭くて空港取 得が比校的容易となり, area navigationや microwave ILS の採用により空の交通潍犨む緩和される利点があ り，将来の交通システムとして真剣に検討されるよう になった。特に文明の発達は学㗢時間の短縮をむたら し、人間の時間価值がますます増大して来るに至って, 都市間の短時間交通はもとより海，山，離島等のレジ ヤ用交通システムとして STOL は新しい観点からあ 見直されるようになってきた. 東京, 大阪等の大都市 の過密化も急速に対策を要する気運が盛上がりつつあ り, 地方都市への人口，経済，文化の分散が検討され るようになって STOL はいよいよその必要性を痛感 される時代が近づきつつある.

新しい STOL システムの開発には, 機体, エンジ ンの開発と相まって，都市計画や国土計画にマッチし た空港計画, 航法システムの研究開発, 関連法規規準 の研究制定等々，難しくて解決に長期を要する問題が 山積している. 昭和 39 年に運行した新幹線は 20 年以 上前の戦時中にたてられた構想計画によるすののだと 聞く．社会的二ーズは加速度的速さを以て押し寄せて 来る時代であるととに想をいたし，すみやかに国とし
ての長期ヴィジョンを策定して計画的な基本研究に着 手する必要があると考える.

\section{参考 文 献}

1) Szlenkier, T. K. : A Common Design Approach to ISTOL and V/STOL Transport Aircraft, Aircraft Engineering, 3/1972.

2) 赤木新介：交通機関論，コロナ社, (1971).

3）社会工学研究所編：都市間交通におけるV/STOL の 役割 (昭和 47 年度研究).

4) FAA Advisory Circular AC 150/5300-8: Planning and Design Criteria for Metropolitan STOL Ports, (1970).

5) 社会工学研究所編：都市間交通における V/STOL の役 割 (昭和46年度研究).

6) White, E.A. et al. : Engines for Civil V/STOL., Aeronautical Journal, 10/1972.

7) Parlett, L.P. et al.: Wind Tunnel Investigation of an External-Flow Jet-Flap Transport Configuration having Full-Span Tripple-Slotted Flaps, NASA TN D-6391, 1971.

8) Phelps, A.E. : Low-Speed Wind-Tunnel Investigation of a Semispan STOL Jet Transport Wing. Body with an Upper-Surface Blown Jet Flap., NASA TN D-7183, 1973.

9) FalARsKI, M.D. et al. : Aerodynamic Characteristics of a Large Scale Model with a Swept Wing and Augmented Jet Flap., NASA TM X-62,029, 1971.

10) Harris, W.P.A. : Factors in STOL Flight Control Configuration., AIAA No. 71-993, 1971.

11) Spirzer, R. E. : Predicted Flight Characteristics of the Augmentor Wing Jet STOL Research Aircraft., NASA CR-114463, 1971.

12) NASA Lewis Research Center. : Aircraft Propulsion., NASA SP-259, 1970.

13) NASA Lewis Research Center: Aircraft Engine Noise Reduction., NASA SP-311, (1972).

14) NASA Ames Research Center : STOL Techhology., NASA SP-320, (1973).

15）层間谕送機開発拹会：CTP-8001, June 1. 1973.

\section{飛行 船 の 再 評 価}

\section{I. 序 論}

飛行船の能力を再評価しようとする動きが世界的に 見られるようになり 2) 5)，我国でも木村秀政博土を中 心とするグループが活発な活動を始められているよう で，社会的関心が高まりつつあるのは宇宙航空関係者 として喜ばしいととである.すなわちこの気運の背景

\footnotetext{
* 昭和 49 年 9 月 24 日原稿受理 Reassessmeut of Aiships
} ***東京大学宇宙航空研究所 Ryojiro AkIBA

$$
\text { 秋 葉 鏡二 郎*** }
$$

としては昨今の公害ブームからその低公害性性が注目 され出したことに加え，加ての飛行船時代に比へ飛

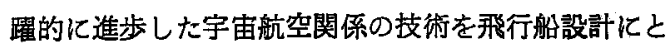
りスれることにより，予想以上の性能や機能をひき出 すととができるのではないかという期待がもたれてい るからであろう.

本文は，乙のような期待をてめて，筆者なりに飛行 船の再検討を試みたものである. 